\title{
PENERAPAN STREAMING NATIVE DALAM PERANCANGAN GALERI KREATIF DIGITAL
}

\author{
Levina Justine ${ }^{1}$
}

${ }^{1}$ Program Studi S1 Arsitektur, Fakultas Teknik, Universitas Tarumanagara, levinajustine00@gmail.com

\begin{abstract}
Abstrak
Sebuah fungsi dalam arsitektur diiringi oleh perilaku yang didominasi oleh perkembangan teknologi hingga mendorong sebuah perubahan pada tipologi lama dan membentuk tipologi yang baru. Genereasi milenial adalah generasi yang lahir pada perabadan dimana teknologi diciptakan sebagai suatu media yang memudahkan para penggunanya dalam beraktivitas. Teknologi berkembang dan memudahkan masyarakat untuk saling terhubung satu dengan yang lain, hingga memiliki sebuah ruang privasi, ruang publik dan dunia untuk individu itu sendiri. Dimana salah satu sifat manusia akan menunjukkan jati dirinya yang telah dipengaruhi oleh dinamika teknologi. StreamingNative adalah suatu perilaku baru yang muncul pada generasi milenial, sebuah perilaku yang dipengaruhi oleh media sosial dengan basis aplikasi tertentu. Masyarakat generasi milenial dengan gawainya sudah menjadi ruang kerja tersendiri, dimana mereka dapat menciptakan, mengunggah, dan menuangkan sebuah pesan dalam bentuk kreativitas ke dalam media sosial. Perilaku Streaming-Native memiliki potensi yang sangat membantu masyarakat generasi milenial dan generasi berikutnya dalam aspek pengembangan kreativitas dan ekonomi. Di samping itu perilaku Streaming-Native dapat menghasilkan tipologi baru dalam fungsi arsitektur, dimana peran arsitektur dapat mendukung perilaku tersebut. Arsitektur sebagai aplikasi baru yang membawa konsepsi dunia tanpa batas dengan pengembangan fungsi galeri seni yang di isi oleh perilaku StreamingNative. Mengkaji kembali sistem media sosial serta peran dan pelaku media sosial terhadap aktivitas masyarakat generasi milenial sehingga muncul sebuah perilaku Streaming-Native dan menerapkan kembali sistem digital tersebut menjadi wujud fisik arsitektur.
\end{abstract}

Kata kunci: aplikasi; dinamika teknologi; ruang milenial; streaming-native; tipologi arsitektur

\begin{abstract}
A function in architecture is accompanied by behavior dominated by technological developments to encourage a change in old typology and form a new typology. Millennial generation were born in the era where technology is created as a media that makes human easier for doing their activity. Technology develops peoples and makes it easier for people to connect with each other, also provide peoples had a privacy space, public space and the world for the individual itself. Wich is human's nature will show their identity which has been influenced by the dynamics of technology. Streaming-Native is one of the new behaviors that appear in the millennial generation, a influenced behaviour by social media on a specific application. The millennial generation community with its gadgets has become a workshop it self, where they can create, upload, express some message in the form of creativity into social media. Streaming-Native behavior has the potential to greatly help the millennial generation and the next generation in the aspects of creativity and economic development. Besides that Streaming-Native behavior can produce a new typology in architectural function, where the role of architecture can support the new behavior. Architecture as a new application that brings a conception of unlimited space by a development of gallery functions were filled by Streaming-Native behavior. Reviewing the social media system, the role and the prepetrators of social media towards the millennial generation's community activities so that a Streaming-Native behavior emerges and re-implements the digital system into a physical form of architecture.
\end{abstract}

Keywords: applications; technology dynamics; millennial space; streaming-native; architectural typology 


\section{PENDAHULUAN}

Awal 2016 sebuah perusahaan ponsel PT.Mobile Ericsson mengeluarkan 10 Tren Consumer Lab untuk memprediksi beragam keinginan konsumen.Jurnal berdasarkan wawancara kepada 4.000 responden yang tersebar di 24 negara dunia. Dari 10 tren tersebut beberapa di antaranya, adalah adanya perhatian khusus terhadap perilaku generasi milenial. Dalam jurnal tersebut telah tercatat, produk teknologi akan mengikuti gaya hidup masyarakat milenial. Sebab, pergeseran perilaku turut berubah beriringan dengan teknologi. "Produk teknologi baru akan muncul sebagai akomodasi perubahan teknologi".

Hasil dari survei membuktikan adanya perilaku baru yang dilakukan yakni perilaku Streaming Native yang berarti: Aplikasi Native adalah aplikasi yang dibangun dengan bahasa pemrograman yang spesifik untuk platform tertentu, contoh : Aplikasi Facebook, Instagram, Youtube dll; sedangkan Streaming adalah pengiriman data berupa konten berbentuk video ke perangkat elektronik seperti komputer atau gawai melalui transmisi internet secara konstan. Tercatat 2011 silam ada 7\% berusia 16 - 19 tahun menghabiskan waktu di depan layar perangkat mobile sekitar 3 jam sehari. Angka tersebut melambung 4 tahun kemudian menjadi $20 \%$. Waktu yang dialokasikan untuk menonton streaming juga meningkat 3 kali lipat. Hasil survei tersebut membuktikan, perilaku generasi milenial sudah tak bisa dilepaskan dari menonton video secara langsung (Live).

Perilaku Streaming Native merupakan gaya hidup baru yang menciptakan sebuah tipe baru dalam arsitektur baik dalam bentuk pengembangan fungsi, pengurangan atau penambahan sistem ruang dalam fungsi maupun pembentukan fungsi arsitektur yang baru. Tipe menghubungan artefak yang memiliki kondisi dan sejarah yang spesifik dengan kelompok objek yang memiliki kondisi umum. Karakter demikian membuat tipe memiliki peran penting sebagai pengikat antara arsitektur dengan konsteksnya.

\section{Rumusan Masalah}

Mengkaji sistem dan unsur-unsur yang di hasilkan oleh perilaku Streaming Native dan di terapkan pada fungsi arsitektur secara fisik yang di ambil dari stereotipe ruang dan fungsi arsitektur yang mewakili aplikasi Native.

\section{Tantangan Proyek}

Perilaku Streaming-Native tentunya belum sering terdengar dikalangan dunia arsitektur namun masalah ini sudah muncul di berbagai bidang lainnya, generasi milenial adalah target dan peran utama dalam perilaku ini. Tentunya di Indonesia perilaku Streaming-Native sudah marak menyebar pada generasi muda Indonesia, namun bagaimanakah tanggapan dan peran arsitektur dalam mengembangkan dan menggunakan perilaku baru tersebut kedalam perekonomian dan leisure didalam kantong kota? Proyek ini meneliti lebih dalam segi perilaku Streaming-Native dengan mengetahui Trend, Habit, Activity yang dilakukan oleh masyarakat generasi milenial untuk mendapatkan sebuah studi steriotipe yang sedang muncul saat ini, usaha penulis dalam proyek ini adalah mengembangkan tipologi galeri seni dengan menyesuaikan perilaku Streaming Native sebagai gaya hidup milenial yang dipengaruhi oleh perkembangan teknologi.

\section{KAJIAN LITERATUR}

\section{Pengertian Generasi Milenial dan Karakteristiknya}

Milenial adalah kelompok demografi Generasi Y, Generasi X dan setelahnya. Para ahli dan peneliti biasanya menggunakan awal 1980-an sebagai awal kelahiran kelompok ini dan pertengahan tahun 1990-an hingga awal 2000-an sebagai akhir kelahiran. Milenial pada umumnya adalah anak-anak dari generasi Baby Boomers dan Gen-X yang tua. Milenial kadangkadang disebut sebagai "Echo Boomers" karena adanya 'booming' (peningkatan besar) tingkat kelahiran pada tahun 1980-an dan 1990-an. Untungnya di abad ke 20 tren menuju keluarga 
yang lebih kecil di negara-negara maju terus berkembang, sehingga dampak relatif dari "baby boom echo" umumnya tidak sebesar dari masa ledakan populasi pasca Perang Dunia II.

Generasi milenial merupakan generasi yang mencari identitas dan hal baru untuk memahami peristiwa dan gagasan di dunia di sekitar mereka. Apa yang mereka lihat dan dengar - dan kesimpulan mereka gambarkan - pengaruhi hidup apa yang mereka hargai, bagaimana mereka mengukur kesuksesan, siapa yang mereka percayai dan prioritas yang mereka tetapkan, termasuk pekerjaan yang akan dimainkan. Anak-anak membangun struktur kognitif, atau peta mental, untuk membantu memahami pengalaman mereka. Karena setiap generasi hidup melalui serangkaian peristiwa yang berbeda selama tahun-tahun pembentukan ini, adalah logis bahwa masing-masing generasi akan membentuk kesan tersendiri dan, sampai batas tertentu, beroperasi di bawah serangkaian aturan yang berbeda.

Umumnya sifat generasi milenial yang menonjol berada pada generasi $\mathrm{Y}$, dikarenakan mereka mengalami sebuah kejadian dimana pengembangan teknologi sedang maju dengan pesat dan adanya aksi terorisme yang mengendalikan mereka untuk mencari aksi atau jalan keluar yang lebih baik. Kedua hal tersebutlah yang membentuk asal usul karakteristik generasi milenial muncul; berikut 2 sudut pandang tentang hal yang mempengaruhi karakteristik generasi milenial :

- Generasi milenial memiliki keberanian dalam bereskperimental dan menghadapi tantangan dengan berbagai strategi untuk mencapai sebuah tujuan dengan cepat dan singkat. Generasi milenial selalu menginginkan segala sesuatu dengan cara instan demi menyingkat waktu untuk mengeksploitasi momen dari pada berfikir panjang untuk masa depan yang tidak pasti.

- Sesuatu yang bersifat umum pada generasi milenial adalah bagaimana mereka mengandalkan teknologi mereka untuk mendapatkan sebuah pekerjaan dengan cara baru. Dimana mereka mengandalkan dan menumbulkan sebuah pertanyaan tentang aplikasi apa yang dapat digunakan untuk menciptakan sebuah pekerjaan baru dan dapat digunakan pada jam kerja. Perusahaan tidak perlu menyediakan fasilitas seperti komputer dan smartphone, karena fasilitas tersebut sudah ada dari mereka sendiri. Dengan menggunakan teknologi baru untuk mendukung generasi ini menimbulkan sebuah "pergeseran waktu" contoh : melakukan hal yang paling nyaman daripada mereka dijadwalkan jam bekerja dan akibatnya "jam kerja" akan hilang dan tergantikan oleh fokus untuk mencapai sebuah kepuasan dan hasil yang baru.

\section{Determinisi Teknologi dan Streaming Native}

Perilaku Streaming-Native memiliki definisi : secara teoritis, streaming adalah pengiriman data berupa konten berbentuk video ke perangkat elektronik seperti komputer atau handphone melalui transmisi internet secara konstan. Sedangkan Native adalah aplikasi yang dibangun dengan bahasa pemrograman yang spesifik untuk platform tertentu, contoh: Youtube, Instagram, Facebook, dan media massa lainnya.

Marshall McLuhan (1962) melalui tulisannya The Guttenberg Galaxy : The Making of Typographic Man. Dasar teorinya adalah perubahan pada cara berkomunikasi akan membentuk cara berpikir, berperilaku, dan bergerak ke abad teknologi selanjutnya di dalam kehidupan manusia. Sebagai intinya adalah determinisme teori, yaitu penemuan atau perkembangan teknologi komunikasi merupakan faktor yang mengubah kebudayaan manusia. Di mana menurut McLuhan, eksistensi manusia ditentukan oleh perubahan mode komunikasi. Perubahan pada mode komunikasi membentuk suatu budaya dengan melalui beberapa tahapan, yaitu :

- penemuan dalam teknologi komunikasi

- perubahan dalam jenis-jenis komunikasi

- peralatan untuk berkomunikasi. 
Teknologi komunikasi yang digunakan dalam media massa tidak dapat dipisahkan dari kehidupan manusia atau menurut Em Griffin (2003) "nothing remains untouched by communication technology" dan dalam perspektif McLuhan, bukan isi yang penting dari suatu media, melainkan media itu sendiri yang lebih penting atau" medium is the message". Contoh yang dapat ditemui dalam realita yaitu perkembangan teknologi yang semakin maju membuat segalanya serba ingin cepat dan instan. Teknologi sebagai peralatan yang memudahkan kerja manusia membuat budaya ingin selalu dipermudah dan menghindari kerja keras maupun ketekunan. Teknologi juga membuat seseorang berpikir tentang dirinya sendiri. Jiwa sosialnya melemah sebab merasa bahwa tidak memerlukan bantuan orang lain jika menghendaki sesuatu, cukup dengan teknologi sebagai solusinya.

\section{METODE PERANCANGAN}

Tahap awal yang dilakukan adalah mengumpulkan data aktivitas kunjungan masyarakat generasi milenial pada suatu fungsi, dari hasil stereotipe yang sering dikunjungi oleh masyarakat generasi milenial berdasarkan aspek mobilitas dan pola pengeluaran (Mobility and Spending Pattern) serta jenis hiburan yang diminati, dengan rentang usia responden: generasi Y yang lahir dari tahun 1981 sampai dengan generasi Z yang lahir dari tahun 1995 hingga 2001.

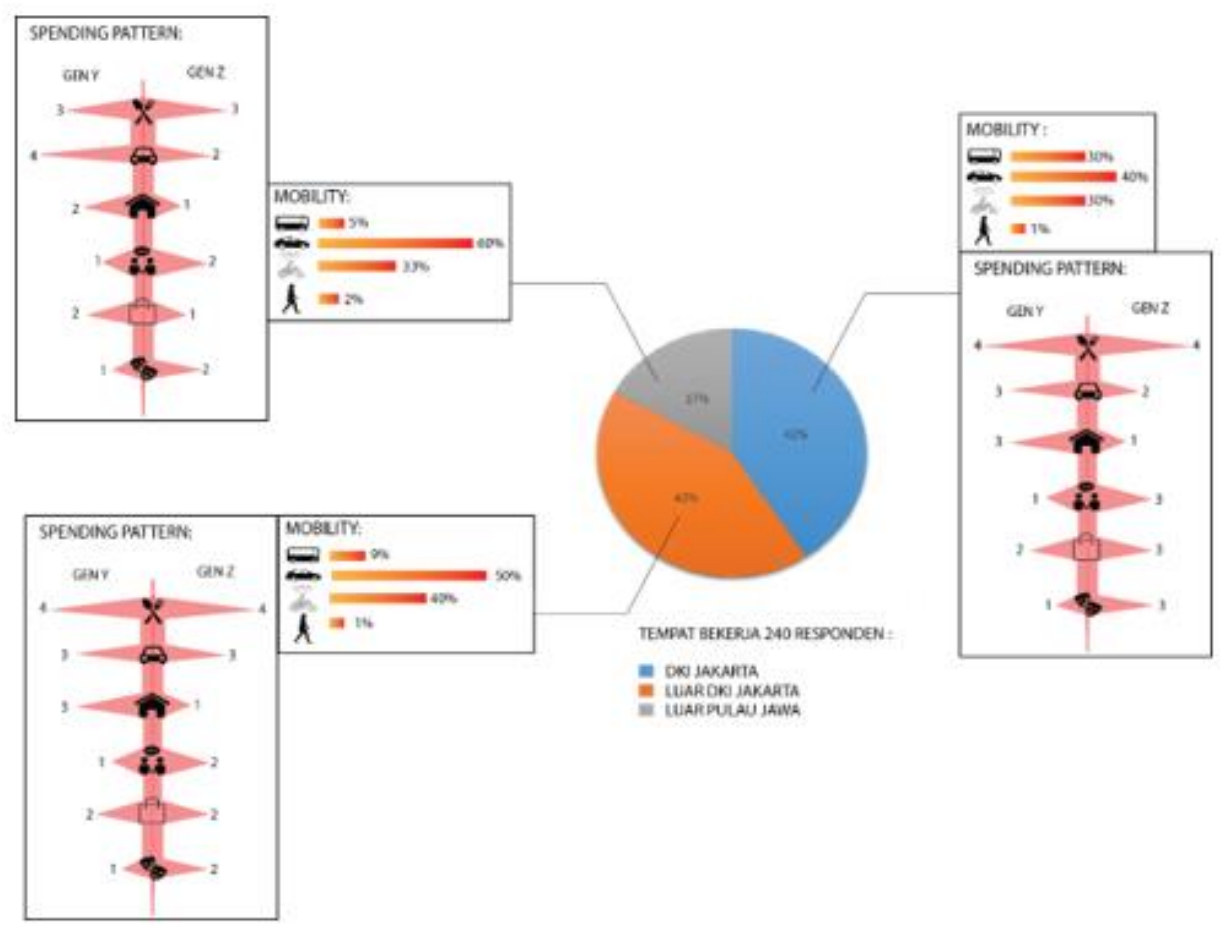

Gambar 1. Hasil Survei "Mobility and Spending Pattern"

Sumber: Penulis, 2019 


\section{STEREOTIPE YANG ADA SAAT INI :}

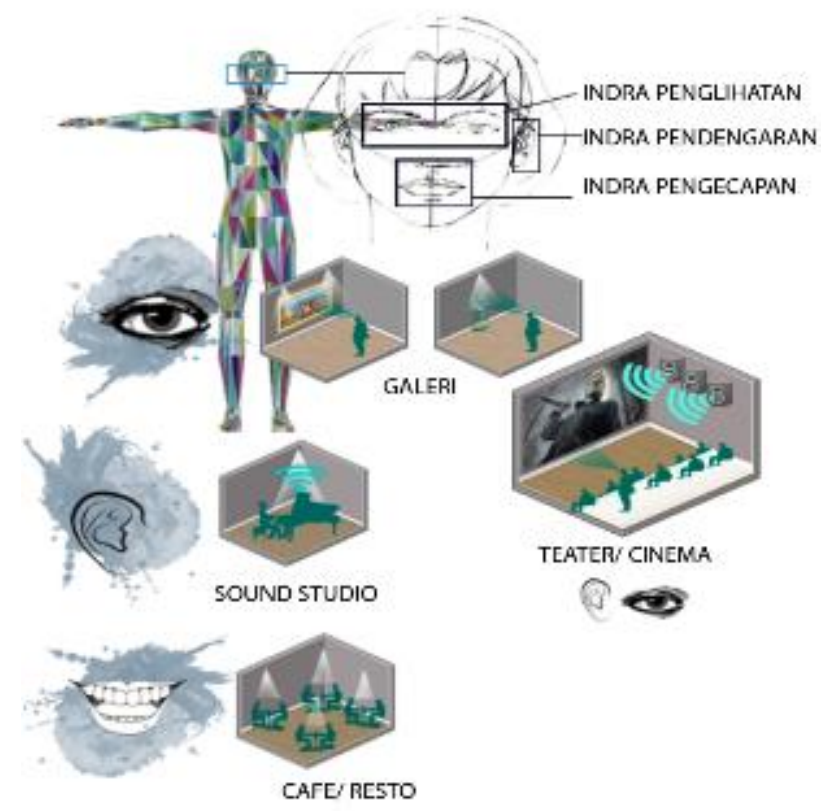

Gambar 2. Stereotipe Fungsi Program Kunjungan Milenial Sumber. Penulis, 2019

Dari hasil data stereotipe yang sering dikunjungi oleh masyarakat generasi milenial, penerapan dalam merancang adalah dengan mengolah program atau fungsi objek rancangan dengan mengembangkan fungsi galeri (gallery) dimana arsitektur sebagai aplikasi Native yang akan dipengaruhi oleh kegiatan Stream di dalamnya serta program di dalamnya berupa stereotype suatu program yang sedang ada saat ini menjadi sebuah tipologi (typology) baru yang dipengaruhi oleh perilaku Streaming, sebagai penerjemah dari arsitektur dekonstruksi.

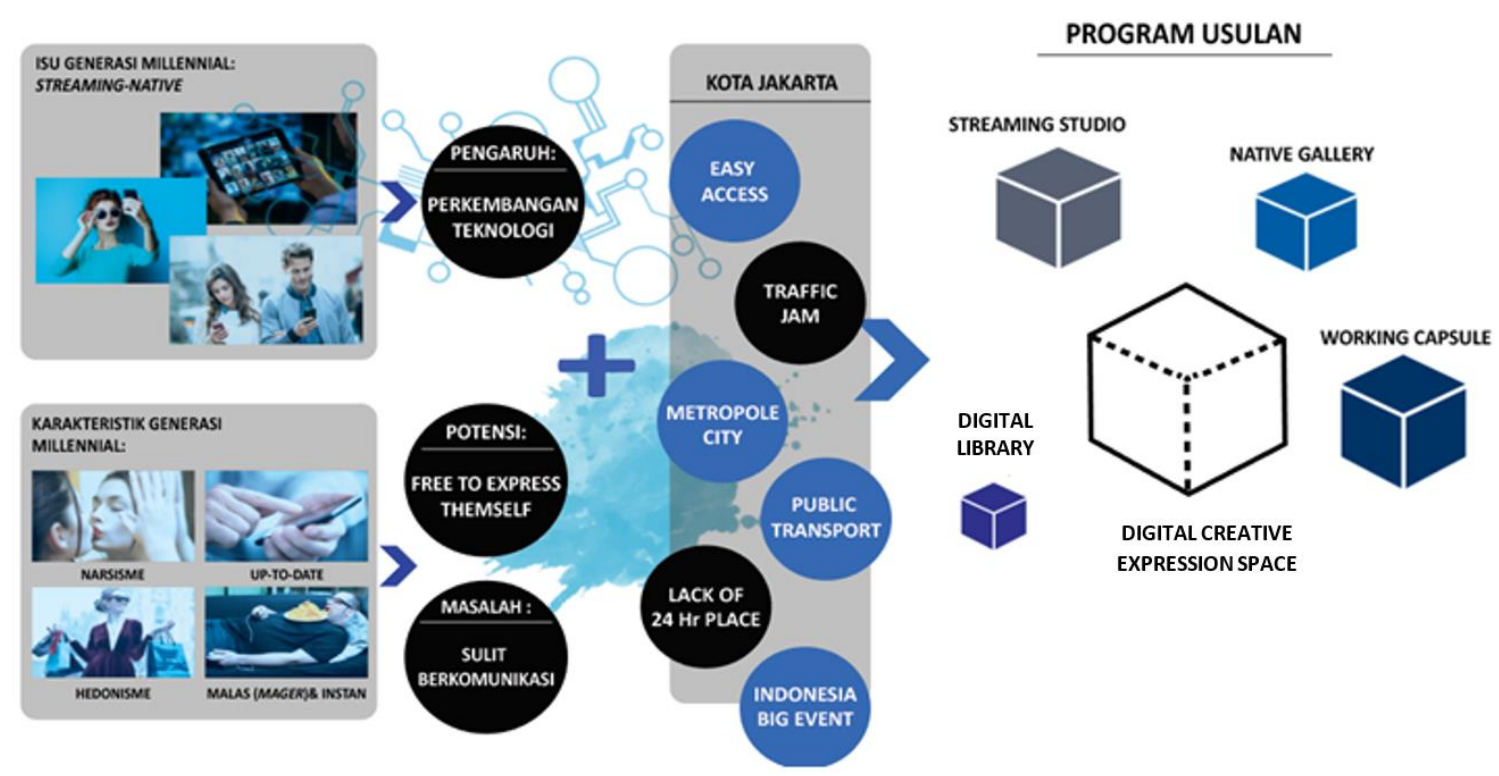

Gambar 3. Pemetaan Analisa Program Usulan Sumber: Penulis, 2019

Tahap yang dilakukan berikutnya adalah menganalisa lebih dalam mengenai aktivitas dan peran yang aktif dalam perilaku Streaming Native dan bagaimana cara bekerja para peran 
tersebut. Terdapat 3 peran utama dalam perilaku tersebut yaitu : Komunitas (Community); Influencer; follower.

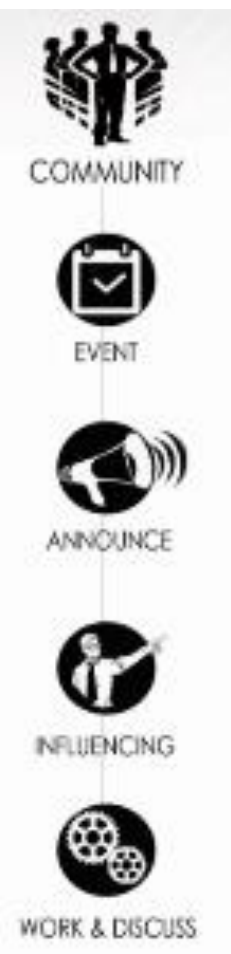

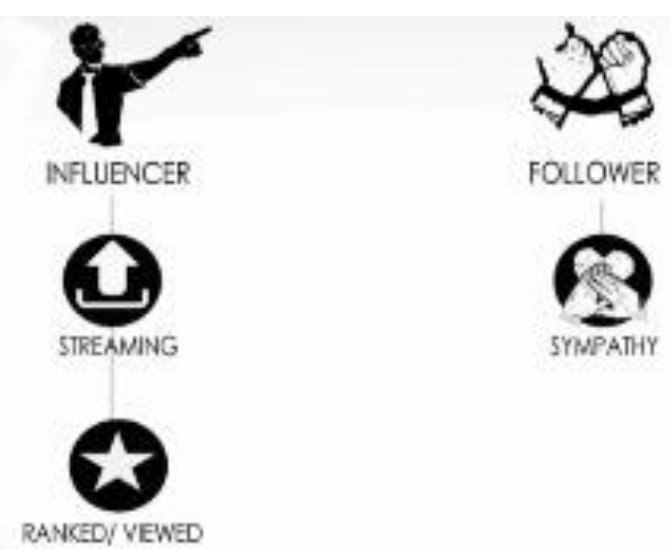

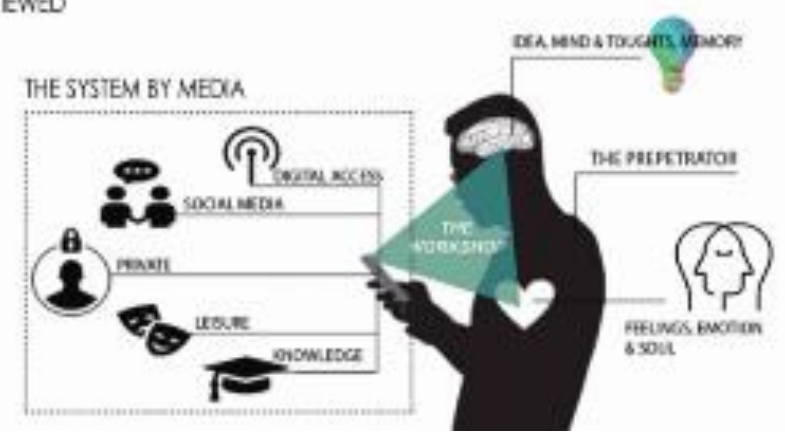

Gambar 4. Aktivtias Peran Streamer

Sumber: Penulis, 2019

Pendekatan yang sejalan untuk tipologi program ini adalah prinsip Narrative Deconstruction yang menjelaskan bahwa sebuah cerita memiliki pemecahan dan penyusunan kembali didalam narasinya, bagaimana sebuah narasi asli dibuat kembali menjadi narasi yang baru. Hal tersebut diterapkan terkait dengan penggunaan teknologi yang mendominasi generasi milenial dalam media sosial dengan perilaku Streaming-Native dalam fungsi rekreatif dan ekonomi serta menciptakan sebuah ruang yang memiliki sebuah cerita untuk setiap momen yang dihasilkan oleh para generasi milenial serta ruang kerja baru yang berfungsi sebagai sarana bekerja dan sebagai wadah untuk menciptakan momen bagi para masyarakat generasi milenial. Narasi yang diangkat adalah narasi yang dikutip dari film Transendence (2014) yang memetakan dunia digital tanpa batas. 


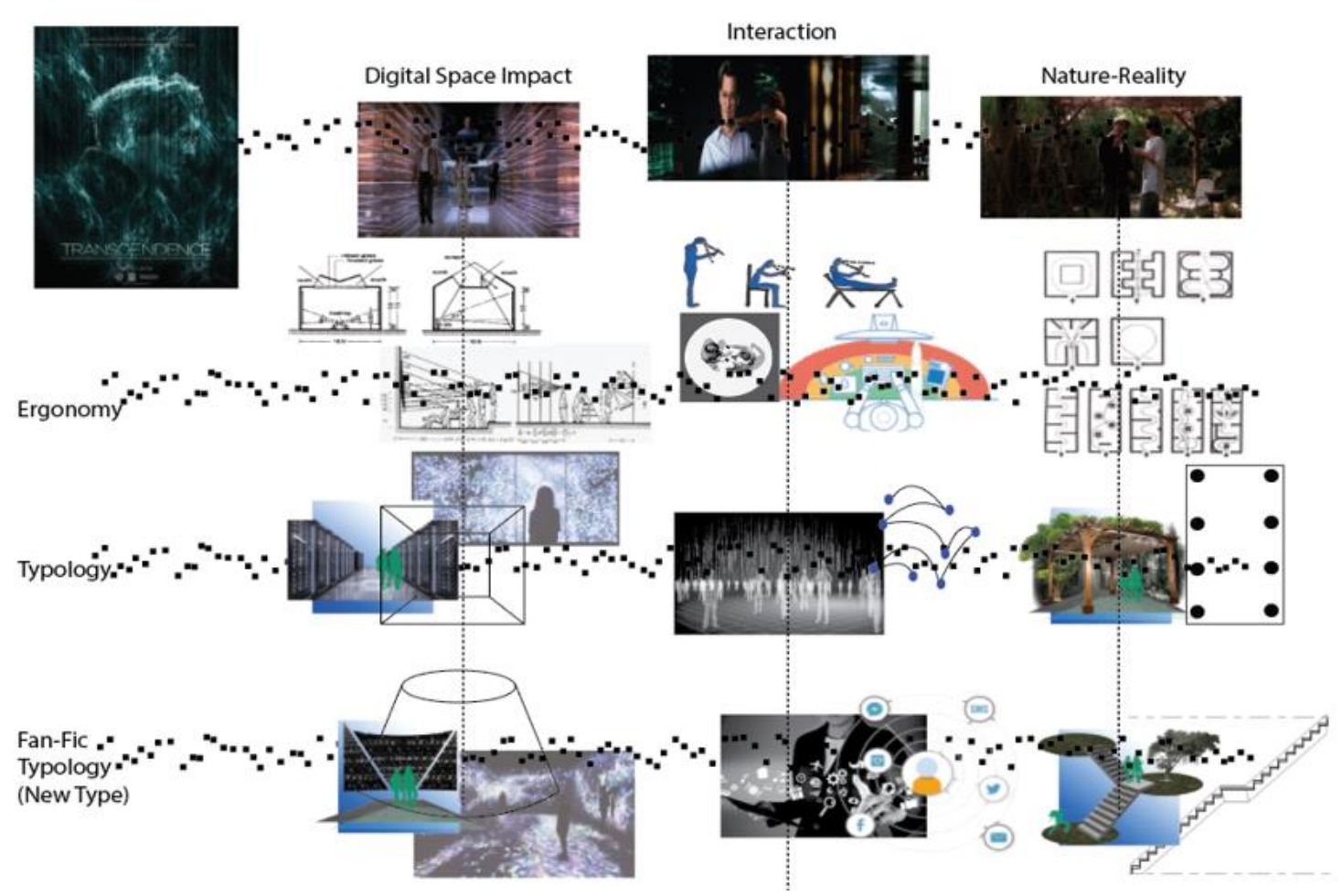

Gambar 5. Narrative Metaphor Film Transendece Sumber: Penulis, 2019

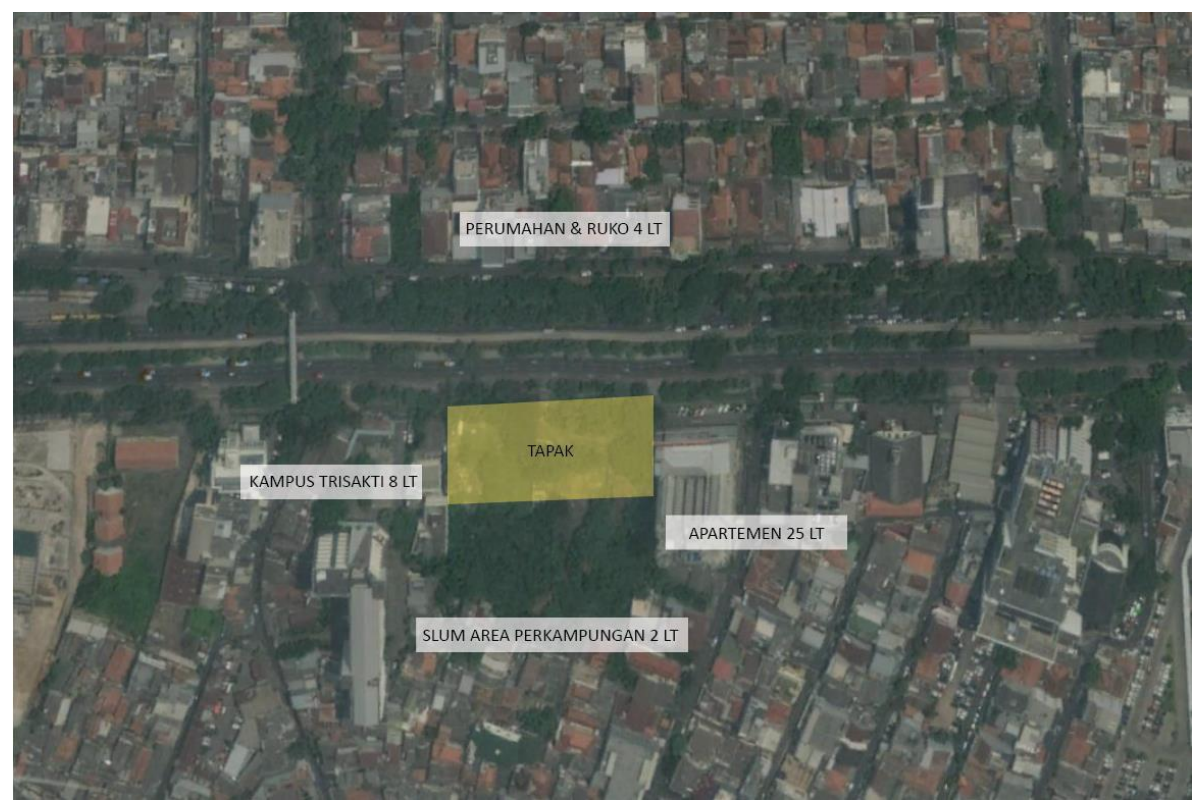

Gambar 6.Tapak Terpilih

Sumber: Penulis, 2019

Hasil dari kriteria penulis memilih kawasan di Jakarta Barat Kecamatan Grogol Pertamburan, dengan pertimbangan nilai harga lahan yang masih memungkinkan dalam pendirian proyek yang diusulkan tidak terlalu mahal. Selain itu pemilihan lokasi juga dipertimbangkan akan tingginya demografi penduduk dalam taraf generasi milenial. Lokasi tapak yang terpilihi yakni Jl.Kyai Tapa RT 5/ RW 9, Kel.Tomang - Kec.Grogol. 


\section{DISKUSI DAN HASIL}

Ruang Ekspresi Kreatif Digital adalah proyek yang berangkat dari sebuah tipe galeri seni dan dipersembahkan untuk generasi milenial sebagai penggerak utama yang sudah lekat dengan perilaku Streaming Native dimana perilaku Streaming Native yang dihasilkan oleh masyarakat antara lain adalah mencari, mendapatkan, melampiaskan maupun mengekspresikan sebuah pesan tersendiri dalam menikmati maupun membuat konten yang diciptakan. Dimana proyek ini menjadi sebuah aplikasi baru yang mendukung para follower, influencer maupun komunitas sosial yang akan mengisi sejumlah konten yang akan dinikmati oleh masyarakat generasi milenial maupun generasi sebelumnya.

Hasil proyek dilakukan dengan adanya pengembangan sistem pada fungsi galeri seni yang tidak memiliki ruang workshop sebagai fisik melainkan ruang workshop itu bekerja secara digital. Permainan ruang dalam yang di dukung oleh berbagai display teknologi yang memiliki sistem aplikasi untuk mendukung arsitektur sebagai aplikasi native.

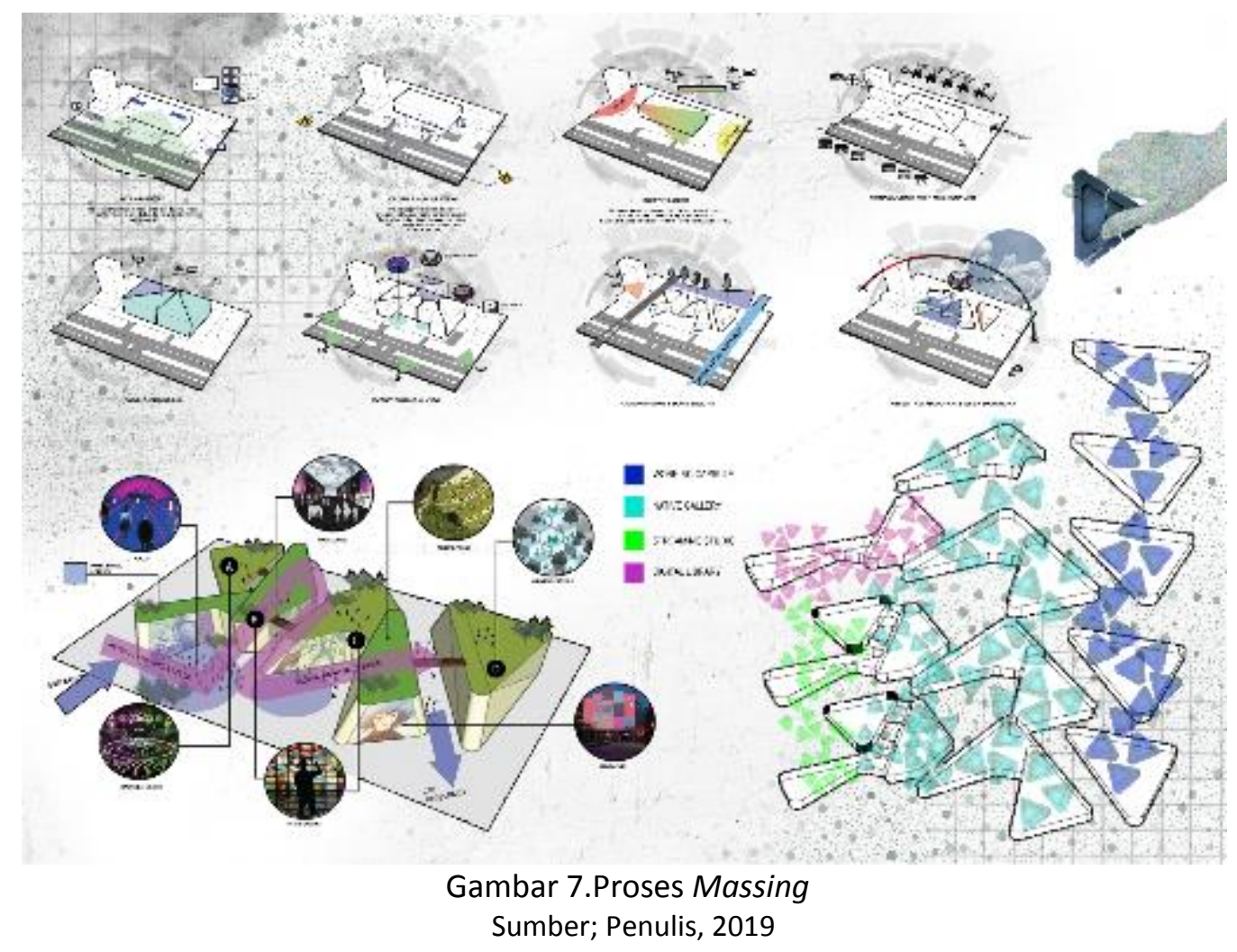

Berikut merupakan gambaran program ruang yang dihasilkan pada proyek dan sistem kerja program ruang tersebut : 


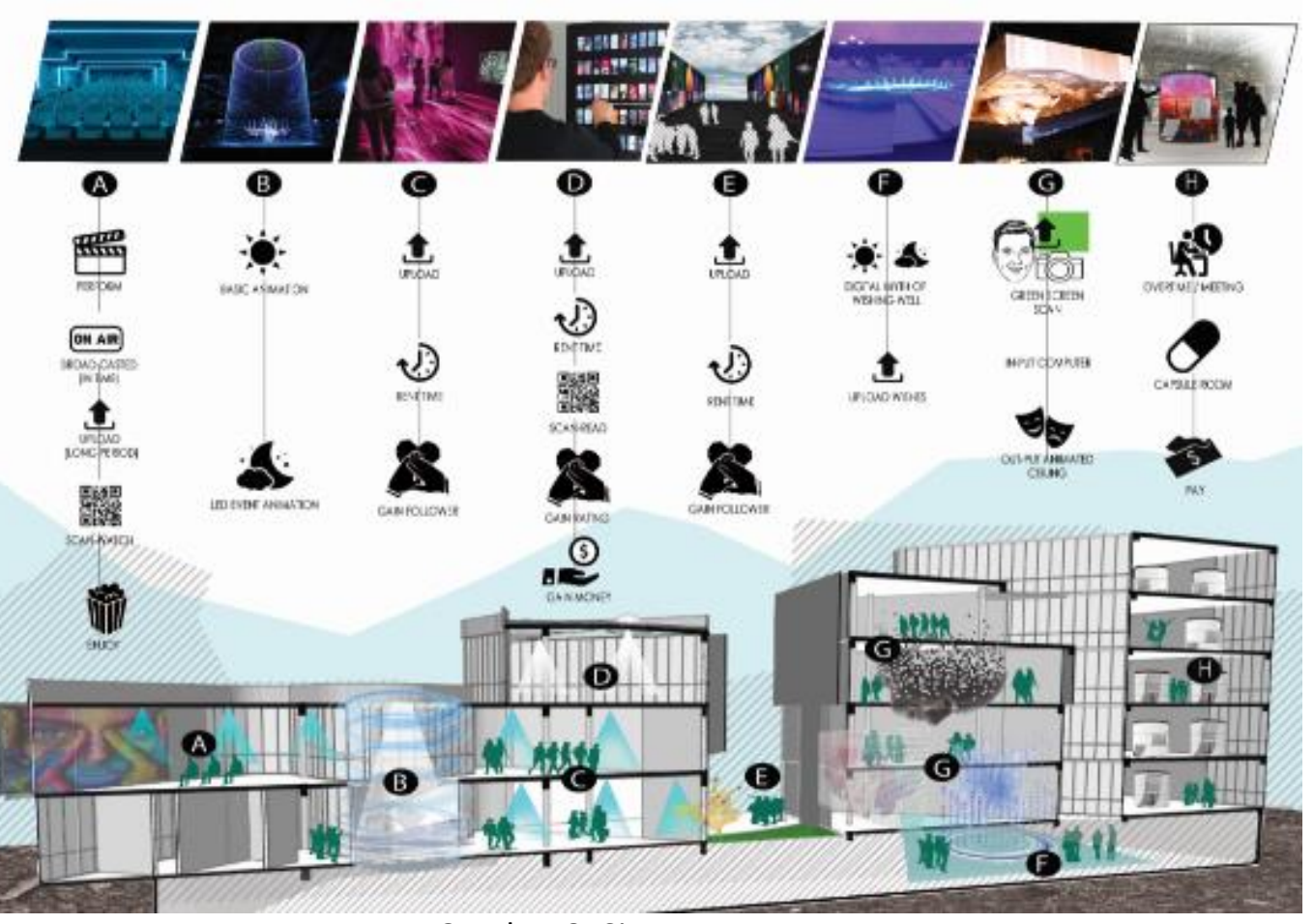

Gambar 8. Sistem Program

Sumber; Penulis, 2019

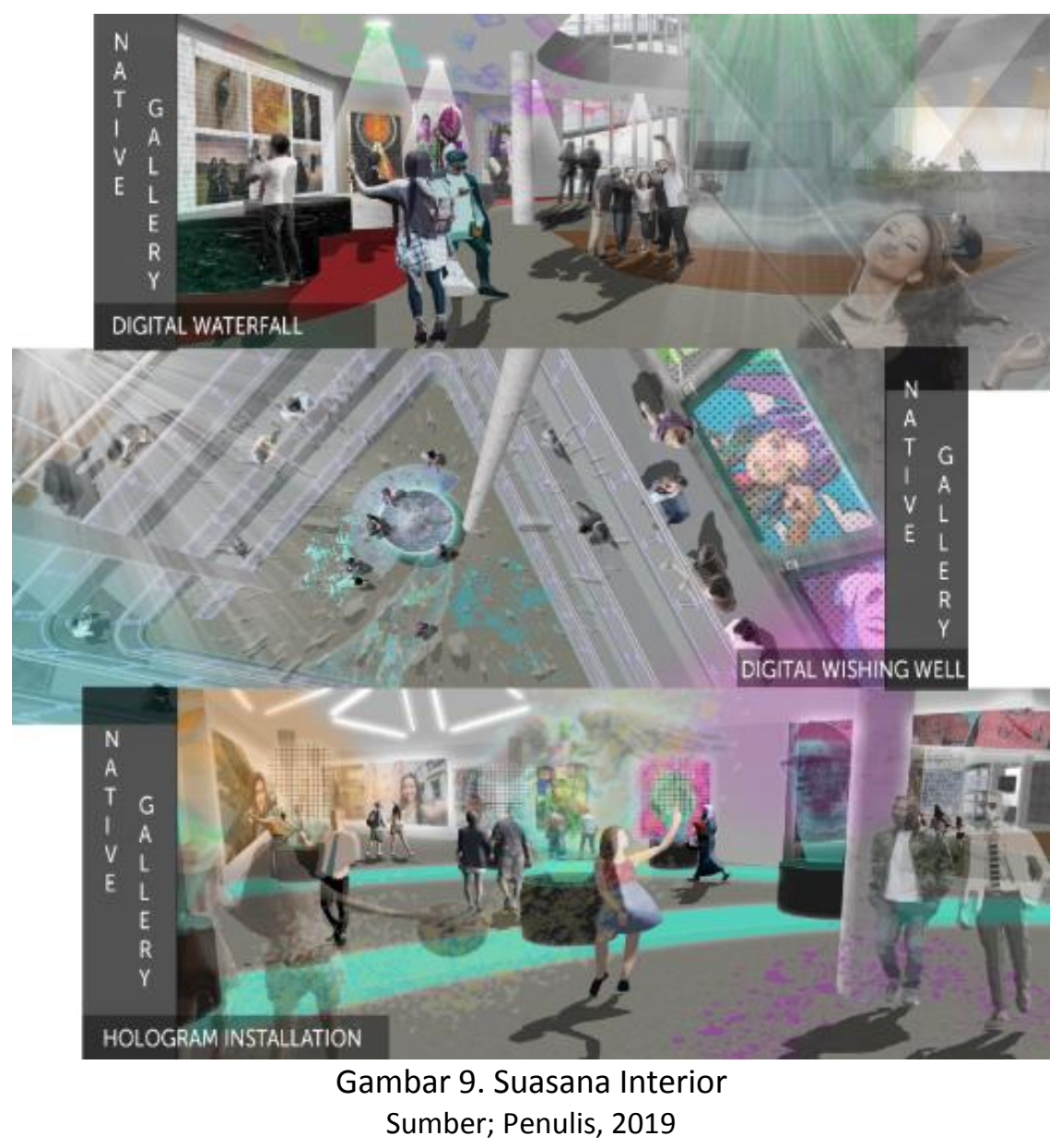




\section{KESIMPULAN DAN SARAN}

Digital Creative Expression Space (Ruang Ekspresi Kreatif Digital) berperan sebagai aplikasi Native yang di pengaruhi oleh perilaku Streaming Native sebagai wadah atau ruang untuk menciptakan momen, konten, menyampaikan pesan secara langsung lewat media yang sudah lekat dengan generasi milenial agar mengembangkan potensi pada dirinya masing-masing dalam kreativitas maupun ekonomi di dalam komunitas baik diri sendiri. Juga sebagai sarana umum yang disesuaikan dengan aktivitas padat generasi milenial di jaman ini, dimana banyak generasi milenial yang membutuhkan area aktivitas 24 jam lebih banyak dan tidak hanya sebuah stereotipe restoran yang lebih banyak pada saat ini.

Saran mengenai penelitian yang memungkinkan untuk dikembangkan adalah pendekatan perancangan Narrative Metaphor terhadap tipologi program yang mengisi dan dipenuhi dengan metafora narasi dunia digital tanpa batas ke dalam sebuah bangunan di era milenial ini, dimana sebuah perilaku muncul di pengaruhi oleh sebuah media dan dikembangkan dengan mengambil potensi-potensi baik yang dapat mengembangkan ekonomi dan kreativitas masyarakat.

\section{REFERENSI}

Agudin,L.M. (1995). The Concept of Type in Architecture: An Inquiry into the Nature of Architectural From. Zurich: Swiss Federal Institute of Technology.

Architectural Design (2002). Poetics in Architecture; editor. Leon Van Schaik. London: Wiley Academy.

Browne, W.A. (2010, November 15). Story Telling In Architecture: Narrative Architecture. Planetizen. Diakses pada 20 Juli 2019 melalui https://www.planetizen.com/node/46878.

De Chiara, J., \& Callender, J. (1973). Time-Saver Standards For Building Types. Edisi Ke 2. New York: Mc Graw - Hill Book Company.

Erickson, T.J. (2012). The Millennials. RSA Journal vol 1568, no.5550, 22-25.

Harari Y.H. (2015). Homodeus A Brief History of Tomorrow. Hebrew.

Hindarto, P. (2005). A studio architect : Pengertian Teras. Astudio. Diakses pada 23 Juli 2018 melalui http://www.astudioarchitect.com/2008/12/teras-rumah-teras-yang-baikadalah.html.

Livikacansera, S (2019, July 23). Mengenal Generasi Milenial: Data Streaming Native Erricsson. Pusat Data Republika. Diakses pada 15 Desember 2018 melalui https://www.republika.co.id/berita/koran/inovasi/16/12/26/ois64613-mengenal-generasimillennial.

Mah,K. (2013). Architecture \& The Human Behaviour. academia.edu.

McLuhan, M. (1962).The Guttenberg Galaxy : The Making of Typographic Man - Determinisi Teknologi.

Monica, T. (2017). Jurnal Teknorat: Implementasi Konsep Media Sosial. https://ejurnal.teknokrat.ac.id/index.php/teknokompak/article/download/64/128.

Neufert, E. (1996). Data Arsitek Jilid II Edisi 33. Trans. Sjamsu Amril. Jakarta. Erlangga.

Portal IImu Komunikasi Indonesia (2018, January 18). 10 Manfaat Komunitas Online di Media Sosial. PakarKomunikasi.com. Diakses pada 1 Juni 2019 melalui https://pakarkomunikasi.com/manfaat-komunitas-online.

Robillard, D.(1982). Public Space Design in Galeris. dc.uwm.edu.

Wirth, L. (1938). Urbanism as a Way of Life. study.com. 